\title{
DEMONSTRATION OF EARLY PREGNANCY FACTOR IN GILTS DURING THE REPRODUCTIVE CYCLE
}

\author{
Z. KNOTEK \\ Department of Swine Disease Prevention, Animal Breeding and Animal Hygiene \\ University of Veterinary Science, 61242 Brno
}

Received Fune 22, 1989

\begin{abstract}
Knotek, Z.: Demonstration of Early Pregnancy Factor in Gilts During the Reproductive Cycle. Acta vet. Brno, 59, 1990: 35-40.

Studies of factors affecting the success of conception and the course of pregnancy are of major importance in the physiology of reproduction. Therefore methods are needed for early detection of pregnancy in farm animals. The object of the present study was to test the usefulness of a modified rosette inhibition test for detection of early pregnancy factor (EPF) in the sera of 40 gilts in different phases of the reproductive cycle. The presence of EPF in serum was confirmed practically throughout the gestation period. The relation between the serum rosette inhibition titres and the phase of the reproductive cycle for groups of inseminated and unmated gilts and for groups of pregnant and non-pregnant gilts was highly significant $\left(X^{2}=77.26\right.$ and 81.38 respectively; $\mathrm{P}<0.01$ ). Upon triplicate examination of all blood serum samples the detection of pregnancy by determination of EPF was successful in $85.7 \%$ of the inseminated gilts. In unmated gilts and primiparous sows the presence of EPF in blood serum was not confirmed. The described method for demonstration of EPF in blood serum of gilts can be of practical value in detecting non-pregnant animals as early as one week after insemination and in assessing the extent of embryonic death.
\end{abstract}

Pregnancy, embryonic mortality, gilt

Studies of factors affecting the success of conception and the course of pregnancy are of major importance in the physiology of reproduction. The underlying difficulty is the necessity to investigate an increasingly larger number of newly defined environmental factors whose possible adverse effects on pregnancy have neither been confirmed nor excluded. A key to the resolution of the problem is the possibility to detect pregnancy as early as possible after conception because the heaviest embryonic loss can be expected to occur between fertilization and completed implantation.

Early pregnancy factor (EPF) was detected in blood serum of pregnant mice (Morton et al. 1976) and subsequently confirmed in other species (in women - Morton et al. 1977; in sheep Morton et al. 1979; in cattle - Nancarrow et al. 1981; in pigs - Paisley et al. 1982).

The present study was designed to look for the presence of EPF in blood serum of gilts during different phases of the reproductive cycle and find whether demonstration of EPF could be used for detection of non-pregnant gilts shortly after insemination.

\section{Materials and Methods}

The experimental animals were 40 Large White and Landrace gilts divided into three groups. Group 1 comprised five 8-month-old unmated gilts. Group 2 comprised gilts 7 days after insemination ( 5 animals), 31 to 56 days after insemination (10 animals), 63 to 65 days after insemination ( 5 animals) and 80 to 85 days after insemination ( 5 animals). Group 3 included primiparous sows 7 to 12 days after farrowing ( 5 animals) and 28 to 32 days after farrowing ( 5 animals).

Serum. Blood samples were collected from the cranial vena cava and the jugular vein in the morning. The sera were inactivated at $56^{\circ} \mathrm{C}$ for 30 minutes and then cooled and frozen. 
Antilymphocytic Serum (ALS). Thymocytes obtained by homogenization of piglet thymi in Hanks solution were washed three times and filtered through sterile gauze. The suspension of $10^{9}$ cells in saline was injected into the ear vein of rabbits five times at weekly intervals. Seven days after the last immunization the rabbits were bled and the sera were inactivated at $56^{\circ} \mathrm{C}$ for $30 \mathrm{mi}$ nutes and frozen.

Complement. Guinea-pig complement was saturated by repeated incubation with sheep erythrocytes ( 3 times for 20 minutes) and pig erythrocytes ( 3 times for 20 minutes) in icy water bath under continuous shaking.

Sheep Erythrocytes. Blood was withdrawn from the jugular vein of a ram into Alsever's solution $(1: 1)$ and stored at $4^{\circ} \mathrm{C}$ for 1 to 2 weeks. On the day of the test the erythrocytes were washed 3 times in Hanks solution and the concentration of $10^{8}$ cells $/ \mathrm{ml}$ was prepared.

Lymphocytes. They were isolated from the peripheral blood of control pigs according to Pospísil et al. (1975) and washed 3 times in Hanks solution. The suspension was prepared in the concentration of $10^{7} \mathrm{cells} / \mathrm{ml}$. The lymphocytes were prepared in the morning hours of the day that the blood serum samples were examined and their viability was checked by the reaction with trypane blue.

Demonstration of EPF in Blood Serum. The presence of EPF was demonstrated using a modified method according to Morton et al. (1983). Lymphocytes $\left(10^{7}\right)$ were incubated with $0.2 \mathrm{ml}$ test serum (diluted $1: 2$ with Hanks solution) at $37^{\circ} \mathrm{C}$ for 30 minutes and washed twice. Afterwards $10^{6}$ lymphocytes were transferred to each test tube containing $0.25 \mathrm{ml}$ ALS (in serial twofold dilutions) and $0.05 \mathrm{ml}$ complement (diluted 1:4). After 90 minutes of incubation at $37^{\circ} \mathrm{C}$ under occasional shaking the tubes were allowed to stand at laboratory temperature for 10 minutes and then $10^{7}$ sheep erythrocytes were added to each tube. The samples were spun in a MPW 340 (Polish Peoplé's Republic) centrifuge at $1000 \mathrm{rpm}$ for 5 minutes and immediately afterwards E-rosettes in each tube were counted. At least 200 lymphocytes were counted in each tube and those with at least three bound erythrocytes were regarded as rosettes. The number of rosettes in individual samples was expressed as percentage of the number of rosettes in control tubes in which ALS was replaced with Hanks solution. In each row of the tubes ( 1 row $=1$ serum examined) rosette inhibition titres (RIT) were computed. The RIT is defined as the highest ALS dilution which causes an inhibition of rosette formation of at least $25 \%$, compared with controls without ALS. This titre is expressed as $\log _{2}$ value of the reciprocal dilution af ALS. Blood serum samples from 3 to 4 gilts and two control samples (one from an unmated gilt and one from a pregnant sow) were examined daily. These control samples were used to exclude possible technical defects during the testing. On the basis of RIT values obtained in control animals the results of examination were classified as + (RIT 14 or higher), \pm (RIT 12) and - (RIT 10 or lower). All sera were examined in triplicate.

The varibility of the results was assessed by means of the geometric mean $\left(x_{g}\right)$ and mode $(\hat{x})$. The relation between RIT and and the phase of the reproductive cycle was assessed by the chi-squared test $\left(X^{2}\right)$ in a $2 \times 2$ contingency table.

Table 1.

Demonstration of the presence of early pregnancy factor (EPF) upon repeated examination of blood serum samples in gilts

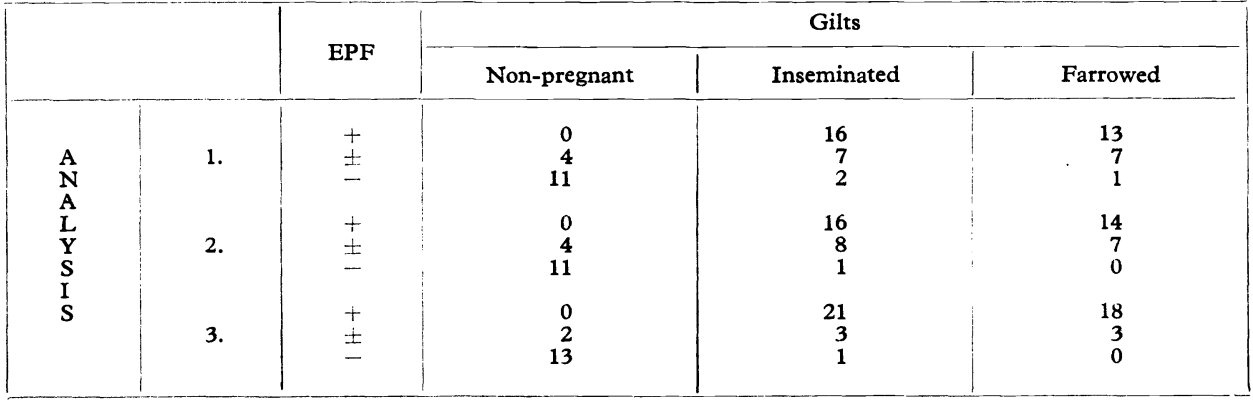

$+=$ presence of EPF in the serum examined $(\mathrm{RIT}=14)$

$\pm=$ dubious result neither confirming nor excluding the presence of EPF in the serum examined $(\mathrm{RIT}=12)$

$-\infty$ absence of EPF from the serum examined $(\mathrm{RIT}=10)$ 


\section{Results}

As can be seen in Table 1 EPF was not demonstrated in the blood serum of any unmated gilt or primiparous sow. Only in two primiparae (7 and 28 days after farrowing) it was not possible to exclude the presence of EPF in their sera unequivocally even after triplicate examination (13.3\%). The mean RIT of the gilts before insemination and after farrowing was $x_{g}=10.42 ; \hat{x}=10.00$.

The presence of EPF was confirmed in the sera of $21(84.00 \%)$ out of 25 inseminated gilts. Three gilts in which the presence of EPF in blood serum was demonstrated between 31 to 34 days after insemination were inseminated again on days 59, 71 and 75, respectively. One gilt in which the presence of EPF in blood serum was excluded 7 days after the first insemination was inseminated again as early as day 23 . The mean RIT of the inseminated gilts was $x-=13.15 ; \hat{x}=$ $=14.00$.

In non-pregnant ( 5 unmated, 10 suckling and 1 inseminated but non-pregnant) animals the presence of EPF in blood serum could be excluded in $75 \%$ (12 out of 16 animals) on the first and second examination and in $87.5 \%$ (14 out of 16 animals) on the third examination of the samples. The mean RIT of these animals was $\bar{x}_{g}=10.39 ; \hat{x}=10.00$.

Fig. 1 shows that the presence of EPF in blood serum could be confirmed by RIT determination practically throughout the gestation period. The relation between RIT and the phase of the reproductive cycle for the groups of inseminated and unmated gilts and for the groups of pregnant and non-pregnant gilts was highly significant $\left(\mathrm{X}^{2}=77.26\right.$ and $\mathrm{X}^{2}=81.38$, respectively; $\left.\mathrm{P}<0.01\right)$.

\section{Discussion}

Pregnancy factors (Ellendorff and Koch 1985) the detection of which is the subject not only of basic research concerning the mother-foetus relation but also of clinical studies have received considerable attention in both human and veterinary medicine. Investigations into the presence of EPF in blood serum of women, for example, made it possible to detect the mechanism of action of intrauterine devices during early pregnancy (Smart et al. 1982) and to define more clearly the contribution of embryonic death to prenatal losses (Smart et al. 1982a; Morton 1984). This factor appears in blood serum shortly after conception (in 4 to 6 hours in mice - Morton et al. 1976; in 6 hours in sheep - Morton et al. 1979 ; in about 48 hours in women - Mort on et al. 1979; after 4 hours in sows Koch et al. 1982). Equally important is the fact that EPF activity disappears rapidly from blood serum after parturition or interruption of pregnancy (Morton et al. 1976; Koch et al. 1982). Therefore EPF detection is useful for studies of embryonic mortality (Straube 1987; Straube 1988 - personal communication).

In the present study EPF was not demonstrated in any unmated gilt or suckling primiparous sow; only in two primiparae it was not possible to exclude the presence of EPF in their sera entirely. In 3 pregnant gilts the presence of EPF could neither be confirmed or excluded unequivocally. Koch and Ellendorff (1985) in their study of the rosette inhibition test in sows reported $8.6 \%$ false positive results and $12.4 \%$ false negative results. The accuracy of the test depends, to a considerable degree, upon the antilymphocytic serum used in the test (Morton 


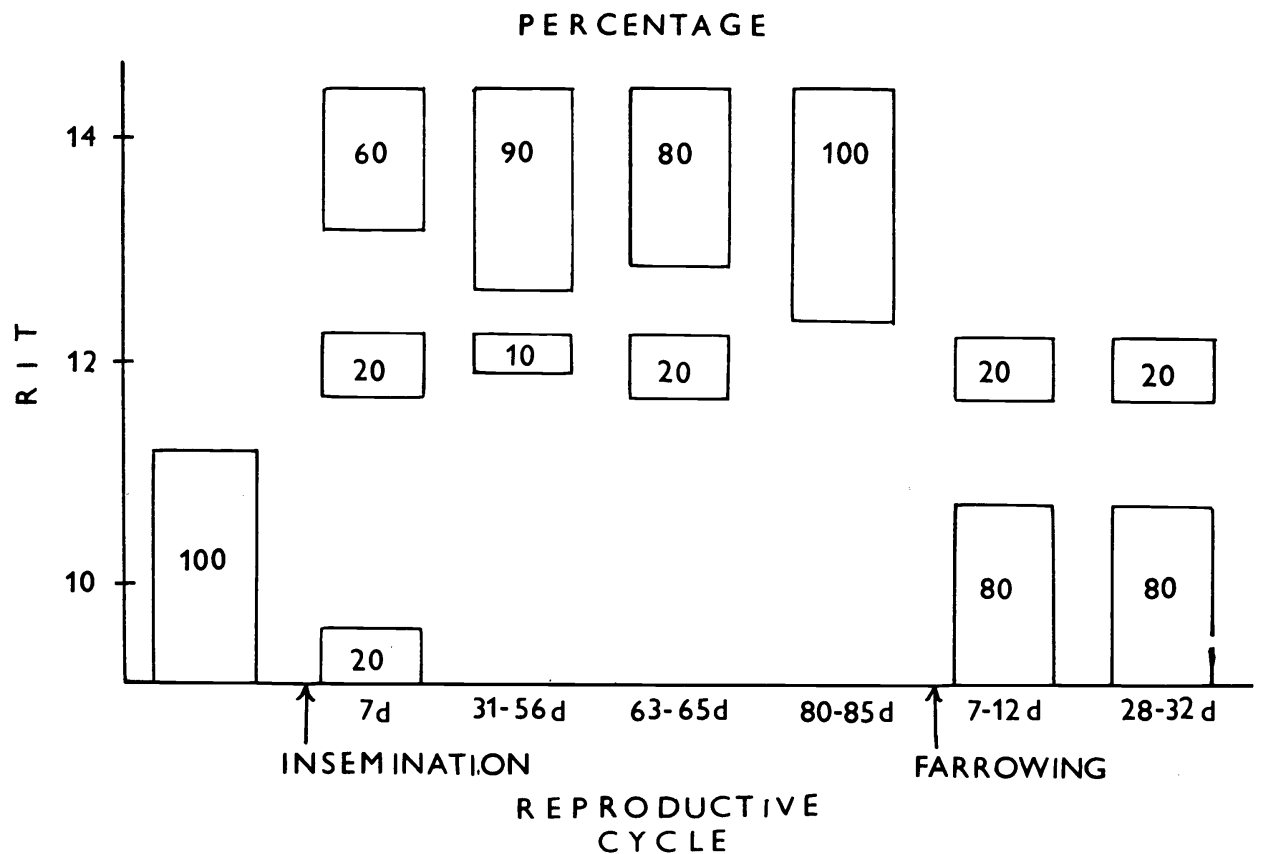

Fig. 1. Rosette inhibition titres (RITs) of the sera of gilts during the reproductive cycle RIT $10=$ Absence of EPF from the serum examined

RIT 12 = dubious result not excluding the presence of EPF in the serum examined RIT $14=$ presence of EPF in the serum examined

et al. 1982). Up to now most laboratories have been working with ALS of their own production and only some laboratories have been using commercial monoclonal antibodies ( $\mathrm{T}$ in ne berg et al. 1984) which, however, do not ensure absolute accuracy of EPF determination either.

In clinical veterinary medicine the determination of EPF in serum of gilts is of value mainly in cases of early embryonic death where new oestrus can be observed during three weeks after the first insemination and where traditional methods of pregnancy diagnosis fail to provide unequivocal evidence whether a conception disorder or a disturbance in embryonic development was the cause. One gilt in the serum of which $\mathrm{EPF}_{\text {in }}$ was not demonstrated 7 days after the first insemination was inseminated again as early as day 23 .

In pigs a decline of serum EPF activity has been reported to occur around 20, 40 and 60 days of gestation and an increased number of false negative samples has been found mainly between 35 and 60 days (Koch and Ellendorff 1985). In the present study these observations were not confirmed. However, the form of test used by the afore-mentioned investigators allows better quantitative assessment of serum EPF activity. The modification used in the present study provides qualitative rather than quantitative results. Moreover, the difference may also be due to the use of antilymphocytic sera of different quality (see above). In keeping with the afore-mentioned investigators our study demonstrated the presence of EPF in serum of gilts practically throughout pregnancy. The demonstration of EPF can be of practical value for the detection of gilts with conception disorders or embryonic death. 


\section{Průkaz EPF (early pregnancy factor) u prasniček $v$ průběhu reprodukčního cyklu}

Studium faktorů, které ovlivňují úspěšnost koncepce a průběh gravidity, je závažným úkolem výzkumu v oblasti fyziologie reprodukce. $Z$ tohoto důvodu je nutno vypracovat metody, které by umožňovaly časnou detekci březosti hospodářských zviřat. Cílem práce bylo ověřit použitelnost modifikovaného testu inhibice rozet k průkazu EPF (Early Pregnancy Factor) v krevním séru čtyřiceti prasniček $\mathrm{v}$ různých fázích reprodukčního cyklu. Prakticky v průběhu celého období březosti bylo možno u sledovaných prasniček přítomnost EPF $\mathrm{v}$ krevním séru potvrdit. Závislost mezi dosaženými rozet - inhibičními titry vyšetřených sér a obdobím reprodučního cyklu prasniček byla pro skupiny prasniček zapuštěných a nezapuštěných i březích a nebřezích vysoce průkazná $\left(X^{2}=77,26\right.$ respektive $X^{2}=81,38$; $\mathrm{p}<0,01)$. Př̀i trojím opakování vyšetření všech vzorků krevních sér byla úspěšnost průkazu březosti pomocí stanovení EPF u inseminovaných prasniček 85,7 \%. U nezapuštěných prasniček a kojících primipar nebyla přítomnost EPF v krevním séru potvrzena. Popsaná metoda průkazu EPF v krevním séru prasniček může být prakticky použita $\mathrm{k}$ vyhledání nezabřezlých prasniček již $\mathrm{v}$ prvním týdnu po inseminaci a $\mathrm{k}$ posouzení rozsahu embryonální mortality.

\section{Определение EPF у свинок в ходе цикла репродүкции}

Изучение факторов, оказывающих влияние на успешность зачатия и ход беременности, является важной задачей исследования в области физиологии репродүкции. По этой причине необходимо заняться разработкой методов, способствующих своевременному выявлению беременности хозяйственных животных. Цель настоящей работы сводилась к тому, чтобы проверить применимость модифицированного теста ингибиции розет для определения EPF (Early Pregnancy Factor) в кровяной сыворотке сорока свинок на разном этапе цикла репродүкции. По сүти дела в течение всего периода беременности у исследуемых свинок можно было наблюдать присутствие EPF в кровяной сыворотке. Зависимость между достигнутыми розет-ингибирующими титрами исследуемых сывороток и периодом цикла репродүкции свинок отличалась у групп осемененных и неосеменных, беременных и небеременных свинок высокой доказательностью $\left(X^{2}=77,26\right.$ или $\left.\mathrm{X}^{2}=81,38 ; \mathrm{p}<0,01\right)$. При троекратном повторении исследования всех образцов сывороток успешность определения беременности с помощью EPF у осемененных свинок достигала 85,7 \%. У неосеменных свинок и впервые кормящих наличие EPF в кровяной сыворотке не было подтверждено. Приведенный метод определения в кровяной сыворотке свинок на практике можно использовать для выявления незабеременевших свинок уже на первой неделе после осеменения и для оценки масштабов эмбриональной смертности. 


\section{Acknowledgements}

I wish to thank Dr. F. Klima of the Akademie der Wissenschaften der DDR, Forschungstelle für Wirbeltierforschung, Berlin, for the modified Hanks solution and MVDr. F. Kovárủ, DrSc., of the Microbiological Institute of the Czechoslovak Academy of Sciences, Prague, for advice and co-operation in the preparation of the rosette inhibition test.

\section{References}

ELLENDORFF, F. - KOCH, E.: Early pregnancy factors. Ithaca (USA), Perinatology Press, 1985, 276p.

KOCH, E.-MORTON, H.-NIEMANN, H.-ELLENDORFF, F.: Early pregnancy factor (EPF) in the pig before and after surgical removal of ova and in relation to their development in culture. Acta endocrin., 99, suppl. 246, 1982, p. 4 (abstr. 4).

KOCH, E.-ELLENDORFF, F.: Prospects and limitations of the rosette inhibition test to detect activity of early pregnancy factor in the pig. J. Reprod. Fertil., 74, 1985: 29-38.

MORTON, H. - HEGH, V.-CLUNIE, G. J. A.: Studies of the rosette inhibition test in pregnant mice: evidence of immunosuppression? Prov. R. Soc. Lond. B., 193, 1976: 413-419.

MORTON, H.-ROLFE, B.-CLUNIE, G. J. A.-ANDERSON, M. J.-MORRISON, J.: An early pregnancy detected in human serum by the rosette inhibition test. Lancet, I, 1977: $394-397$.

MORTON, H.-CLUNIE, G. J. A. - SHAW, F. D.: A test for early pregnancy in sheep. Res. vet. Sci., 26, 1979: 261-262.

MORTON, H.-TINNEBERG, H. R.-ROLFE, B.-WOLF, M.-METTLER, L.: Rosette inhibition test: A multicentre investigation of early pregnancy factor in humans. J. Reprod. Immunol., 4, 1982: 251-261.

MORTON, H.-MORTON, D. J.-ELLENDORFF, F.: The appearance and characteristics, of early pregnancy factor in the pig. J. Reprod. Fertil., 68, 1983:437-446.

MORTON, H.: Early pregnancy factor (EPF): a link between fertilization and immunomodulation. Austral. J. biol. Sci., 37, 1984: 393-407.

NANCARROW, C. D. - WALLACE, A. L. C. - GREWAL, A. S.: The early pregnancy factor of sheep and cattle. J. Reprod. Fertil., suppl., 30, 1981: 191-199.

PAISLEY, L. G. - DAVIS, W. C.-ANDERSON, P. B.-MICKELSEN, W. D.: Detection of early pregnancy factor in swine: A need for dialogue. Theriogenology, 18, 1982: 393-401.

POSPIŚIL, Z.-MACHATKOVÁ, M.-MENŠfK, J.-RODÁK, L.-MÚLLER, G.: Decline in the phytohaemagglutinin responsivenes of lymphocytes from calves infected experimentally with bovine viral diarrhoea-mucosal disease virus and parainfluenza 3 virus. Acta vet. Brno 44, 1975: $369-375$.

SMART, Y. C.-FRASER, I. S.-CLANCY, R. L.-ROBERTS, T. K.-CRIPPS, A. W.: Early pregnancy factor as a monitor for fertilization in women wearing intrauterine devices. Fertil. Steril., 37, 1982: 201-204.

SMART, Y. C.-FRASER, I. S.- ROBERTS, T. K.-CLANCY, R. L.-CRIPPS, A. W.: Fertilization and early pregnancy loss in healthy women attempting conception. Clin. Reprod. Fertil., 1, 1982a: 177-184.

STRAUBE, W.-GÖRETZLEHNER, G.-LOH, M.-SCHÜTZ, M.-NEHMZOW, M.: Detection of the early pregnancy factor (EPF) in the serum of patients with a doubtful pregnancy. Zbl. Gynäkol., 109, 1987: 968-973.

STRAUBE, W. - personal communication (Varna) 1988.

TINNEBERG, H. R.-STAVES, R. P.-SEMM, K.: Improvement of the rosette inhibition assay for the detection of early pregnancy factor in humans using the monoclonal antibody Anti-Human-Lyt - 3. Amer. J. Reprod. Immunol., 5, 1984: 151-156. 